University of Wollongong

Research Online

Faculty of Business - Papers (Archive)

Faculty of Business and Law

$1-1-2015$

\title{
Financial distress: Lifecycle and corporate restructuring
}

Sze Koh

Singapore Institute of Technology

Robert Durand

Curtin University

Lele Dai

University of Western Australia

Millicent M. Chang

University of Western Australia, mchang@uow.edu.au

Follow this and additional works at: https://ro.uow.edu.au/buspapers

Part of the Business Commons

Research Online is the open access institutional repository for the University of Wollongong. For further information contact the UOW Library: research-pubs@uow.edu.au 


\title{
Financial distress: Lifecycle and corporate restructuring
}

\author{
Abstract \\ A firm's lifecycle consists of birth, growth, maturity and decline. We examine the strategies that firms \\ choose when facing financial distress and present evidence that these choices are influenced by the \\ corporate lifecycle. This influence is most pronounced in the choice of financial restructuring strategies \\ such as reducing dividends or changing capital structure. We also examine if the way firms face financial \\ distress affects the likelihood of recovery. We find that reducing investment and dividends are associated \\ with recovery for all firms, but there is little influence of lifecycle. \\ Disciplines \\ Business \\ Publication Details \\ Koh, S., Durand, R. B., Dai, L. \& Chang, M. (2015). Financial distress: Lifecycle and corporate restructuring. \\ Journal of Corporate Finance, 33 19-33.
}




\title{
Financial Distress: Lifecycle and Corporate
}

\section{Restructuring}

\author{
SzeKee $\mathrm{Koh}^{*}$, a \\ Robert B. Durand ${ }^{\mathrm{b}}$ \\ Lele Dai ${ }^{\mathrm{c}}$ \\ Millicent Chang ${ }^{\mathrm{c}}$
}

JEL classification: G33, G34

Keywords: Lifecycle Theory, Financial Distress, Restructuring, Distance to Default

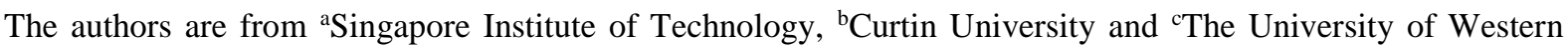
Australia Business School.

*Corresponding author: E-mail: SzeKee.Koh@SingaporeTech.edu.sg

Address: 10 Dover Drive, Singapore 138683 Tel +65 65928635 Fax: +65 65921190 


\title{
Financial Distress: Lifecycle and Corporate
}

\section{Restructuring}

\begin{abstract}
A firm's lifecycle consists of birth, growth, maturity and decline. We examine the strategies firms choose when facing financial distress and present evidence that these choices are influenced by the corporate lifecycle. This influence is most pronounced in the choice of financial restructuring strategies such as reducing dividends or changing capital structure. We also examine if the way firms face financial distress affects the likelihood of recovery. We find that reducing investment and dividends are associated with recovery for all firms, but there is little influence of lifecycle.
\end{abstract}

JEL classification: G33, G34

Keywords: Lifecycle Theory, Financial Distress, Restructuring, Distance to Default 


\section{INTRODUCTION}

Firms move through different stages of the corporate lifecycle as they grow and mature (Miller and Friesen 1984). Financial distress, default and bankruptcy are fundamental stages in the lifecycle of firms (Wruck 1990). This paper examines how firms at different stages of the corporate lifecycle face financial distress, and how the choice of financial restructuring strategies adopted in response are influenced by the corporate lifecycle.

Our measure of distress is based on a firm's distances-to-default (Merton, 1974). Falling distance-to-default metrics for a firm suggests that it is approaching default; increasing distances-to-default indicate that firms are less likely to default. A firm that moves towards default and then away again may be thought of as recovering. We find that firms take responsive actions when in financial distress. However, distinct lifecycle characteristics affect the choice of restructuring strategies these firms undertake. When we consider how firms face financial distress, we can also consider if their strategies affect the likelihood of recovery. We find that reducing investment and reducing dividends are associated with recovery for all firms. In contrast, issuing debt has a negative association with recovery. We find no association of lifecycle with the likelihood of recovery but some evidence that lifecycle and the choice of a strategy is associated with recovery. We also find evidence that adopting at least three strategies when confronting financial distress is associated with recovery. Adopting more than three strategies, however, has no significant association with recovery.

For investors, firms engaging in distress motivated restructuring shows signs of performance improvement (Jensen, 1989; Whitaker, 1999). For managers, it is imperative that the right type of preventative measures are taken when they recognize that their firm is in distress. These restructuring strategies should be proper and appropriate for the stage of lifecycle the firm is in and hopefully, effective to turn the firm around from distress. For policymakers, there is a risk of managers of distress firms taking the wrong and lifecycle- 
inconsistent restructuring decisions that can be detrimental to macroeconomic and financial stability. Therefore, the importance of restructuring strategies in a firm's recovery from distress forms the motivations of this paper.

In Section 2 we discuss previous studies of lifecycle theory, financial distress and corporate turnaround strategies. In Section 3 we describe our data and sample selection. We present our analyses and findings in Sections 4 and 5, and our conclusions in Section 6.

\section{LITERATURE REVIEW}

\subsection{Lifecycle theory}

Lifecycle theory suggests that appropriate growth and capital capacity strategies vary at different stages of a firm's lifecycle (Anthony and Ramesh 1992), which consists of four stages: birth, growth, maturity and decline. Each stage exhibits significant differences in terms of situation, organizational strategy, structure, and decision-making style (Adizes 2004; Miller and Friesen 1984; Pashley and Philippatos 1990).

Firms in the birth stage are typically small, dominated by their owners (entrepreneurs), simple, informal in structure, undifferentiated, and with highly centralized power systems and considerable focus on innovation (Miller and Friesen, 1984). These firms face significant uncertainty over future growth, which is manifested in higher book-to-market ratios and greater firm-specific risk (Lubos and Peitro 2003; Pastor and Veronesi 2003). Firms at the growth stage are typically medium sized with multiple shareholders, and achieving rapid growth. Managers are given more decision-making responsibility, and a separation of ownership and control begins to emerge (Miller and Friesen 1984; Mueller, 1972). Mature and decline firms are less likely to take on innovative or risky strategies than in their birth and growth stages. In these later stages, Mueller (1972) argues, internal fund flows eventually outpace investment opportunities and the cost of capital decreases as uncertainty is reduced. Mature firms aim for the smooth functioning of the business in a well-defined market (Miller 
and Friesen 1984). Firms in decline are encroaching stagnation and suffer from low profitability (Miller and Friesen 1984) and predominantly adopt a 'harvest' strategy where the main aim is the collection of as much funds from existing operations as possible (Thietart and Vivas 1984).

\subsection{Financial distress and corporate turnaround strategies}

Chen, Weston, and Altman (1995) define distress as the condition where a firm's liquidation of total assets is less than the total value of creditor claims. If prolonged, this situation can lead to forced liquidation or bankruptcy; for this reason, financial distress is often referred to as the likelihood of bankruptcy, which is dependent on the availability of liquidity and credit (Hendel 1996). When a firm recognizes that it is in danger of financial distress, it is vital that it responds immediately by taking corrective measures to enhance efficiency and control costs. Denis and Kruse (2000) find that, when a firm is in distress, restructuring is associated with positive abnormal returns.

Sudarsanam and Lai (2001) provide four classifications of restructuring: managerial, operational, asset, and financial. Managerial restructuring includes replacement of senior management and/or the Chief Executive Officer. Managers whose poor planning or inefficient decision-making are considered the cause of financial distress may be replaced with new teams to assess the source of distress and implement strategies for turnaround (Lohrke, Beheian, and Palmer 2004); Pearce and Robbins (1993) stress the importance of management in turning distressed firms around. Denis and Kruse (2000) find that $36 \%$ of the sample firms they studied experienced such turnover in top executive positions following performance declines.

Operational restructuring aims to restore profitability by controlling costs and reducing overheads through the sale of surplus fixed resources such as land, equipment and offices. By 
decreasing input and maximizing output, firms can generate cash flow and enhance efficiency, at least in the short term: if used as a stand-alone strategy, it may not be enough to bring about recovery (Sudarsanam and Lai 2001), so is primarily a short-term fix to generate cash flow quickly.

When a distressed firm sells off unprofitable or non-core lines of business, it is considered to be engaging in asset restructuring. This form of restructuring aims to realign the focus of the firm by reducing unrelated diversification and refocusing the business portfolio on core competencies (Shleifer and Vishny 1992). Selling underperforming businesses allows their share of resources to be redeployed towards better uses; asset restructuring is therefore generally considered to be value-adding (Atanassov and Kim 2009). It has been found to play an important role for distressed firms as it provides both a source of funds and acts as a mechanism for creditors to obtain control over assets (Brown, James and Mooradian 1994).

Financial restructuring generally refers to changes in a firm's dividend policies or capital structure. It seeks to reduce payment pressures by employing equity-based and debt-based strategies. Equity-based strategies may involve dividend cuts or issuance of shares as a means to retain or generate funds; debt-based strategies include the adjustment of interest, debt maturity, or debt/equity ratio. Funds retained are then used to pay debt obligations. DeAngelo and DeAngelo (1990) find that large firms are likely to respond to distress with rapid and aggressive dividend reductions.

\subsection{Restructuring effectiveness}

Various factors affect the success of restructuring strategies. Moulton and Thomas (1993) find that firm size dominates all other variables in successful reorganization. Barker and Duhaime (1997) argue that a successful turnaround depends on the firm's ability to 
change its strategy, structure, and ideology rather than on restructuring based on short-term efficiency or cost-cutting tactics. In particular, cost cutting and layoffs are found to be ineffectual by Denis and Kruse (2000), who consider that improvements in operating performance are mostly attributable to asset restructuring.

\section{DATA}

We investigate the implications of lifecycle theory on the choice of restructuring strategies in firms faced with distress. Our sample is constructed from US firm data available on CRSP and COMPUSTAT between 1995 and 2013. This period includes the Global Financial Crisis (Blinder, 2013) a time when firms faced considerable financial challenges. Our sample excludes firms in the utilities and financials industries since these operate in more regulated environments in terms of capital structure and operations. First, we classify our firms into their lifecycle stages. Next, we identify firms that are financially distressed and those that are not. Finally, we use a series of proxies to determine which restructuring strategies are used by our sample firms.

\subsection{Identification of lifecycle}

We adopt Anthony and Ramesh's (1992) method ${ }^{1}$ of classifying firms into the four lifecycle classifications: birth, growth, maturity and decline, based on the following four lifecycle descriptors: annual dividends, scaled by income; percentage of sales growth; capital expenditure as a proportion of firm value; and the age of the firm:

1. Annual dividend as a percentage of income (DP)

$$
\mathrm{DP}_{\mathrm{t}}=\left(\frac{\mathrm{DIV}_{\mathrm{t}}}{\mathrm{IBED}_{\mathrm{t}}}\right) \times 100
$$

\footnotetext{
${ }^{1}$ Dickinson (2011) develops a firm-level life-cycle proxy based on the predicted behavior of operating investing and financing cash flows across different life cycle stages. We considered Dickinson's method and our results remained unchanged; hence, we report only the results found based on Anthony and Ramesh's method in this paper.
} 
2. Percent sales growth (SG)

$$
S G_{t}=\left(\frac{S G_{t}}{S G_{t-1}}\right) \times 100
$$

3. Capital expenditure as a percentage of total value of the firm (CEV)

$$
\mathrm{CEV}_{\mathrm{t}}=\left(\frac{\mathrm{CE}_{\mathrm{t}}}{\text { VALUE }_{\mathrm{t}}}\right) \times 100
$$

\section{Age of the firm (AGE)}

$\mathrm{DIV}_{\mathrm{t}}$ is the common dividends for a firm in year t. IBED $\mathrm{I}_{\mathrm{t}}$ is the income before extraordinary items and discontinued operations in year t. SALES $\mathrm{t}_{\mathrm{t}}$ is the net sales in year $\mathrm{t}$. $\mathrm{CE}_{\mathrm{t}}$ is the capital expenditure in year $\mathrm{t}$. VALUE $\mathrm{E}_{\mathrm{t}}$ is the market value of equity plus book value debt at year t. Finally, $\mathrm{AGE}_{\mathrm{t}}$ is the number of years where information is available for the firm on CRSP/Compustat. Since industries vary in their dividend payment, sales growth, capital expenditure and age, we adapt Anthony and Ramesh's (1992) approach by controlling for industry effects when grouping firms into the four lifecycle categories. We first calculate the four lifecycle descriptors for each year for each sample firm, then compute median values of the descriptors for each firm-year, using five years' data (i.e., current year and the four previous years). Next, using Fama and French's 49 industry grouping, we split the median values of the descriptors (for each industry) into quartiles and group the firms by lifecycle category. Once a firm-year is assigned to a category, it is given a score (median values less than $\mathrm{Q} 1=1$, between $\mathrm{Q} 1$ and less than $\mathrm{Q} 2=2$, between $\mathrm{Q} 2$ and less than $\mathrm{Q} 3=3$ and equal to Q3 and above =4). We tally the scores for each firm-year and split all observations into quartiles again. Firms are finally categorized into a lifecycle classification based on the cutoff values of the quartiles. 


\subsection{Identification of distress}

Capturing financial distress is central to our paper. Asquith, Gertner and Scharfstein (1994) argue that a firm is in distress if in any two consecutive years its earnings before interest, taxes, depreciation and amortization (EBITDA) are less than its reported expenses. Sudarsanam and Lai (2001) use Taffler's Z-score and adopt a positive, positive, negative approach to define a financially distressed firm as one which has positive Z-scores in the two previous years and a negative Z-score in the current year.

Accounting data records what has been, not what is expected. While we do not wish to enter into debate regarding the efficacy of financial statement analysis, the metrics discussed in the preceding paragraph may be insufficient because of their reliance on accounting data; therefore, we turn to option pricing theory and utilize a measure of the ex-ante likelihood of default. ${ }^{2}$ Merton (1974) models the value of a firm's equity as a call option on its assets, an approach that allows the calculation of a firm's distance-to-default, “...the number of standard deviation decreases in a firm's asset value that it would take for the firm to default" (Sundaram and Yermack, 2007, p.p. 1580-81). In calculating distance-to-default, we follow Bharath and Shumway (2008); the distribution of our estimates of distance-to-default and the probability of default are in keeping with Bharath and Shumway's estimates.

Distance-to-default does not, in itself, tell us when a firm is distressed. We determine if a firm is distressed by following Asquith, Gertner and Scharfstein (1994) and Sudarsanam and Lai (2001). We classify a firm as financially distressed when it has two consecutive years

\footnotetext{
${ }^{2}$ Our study captures firms in extremis but not firms which have become bankrupt. Firms filing for bankruptcy under Chapter 7 cease business; the questions of lifecycle and strategy do not apply. If firms file under Chapter 11, they undertake measures to resolve their financial distress and questions of lifecycle and strategy may apply; however, they may not continue to trade publicly, so access to the variables that we require to compare them with those in our sample will not be systematically available. The UCLA-LoPucki Bankruptcy Research Database (http://lopucki.law.ucla.edu/index.htm) provides information about the largest US bankruptcies, but the data available is different from that required by the experimental design in this paper. We leave questions of strategy and lifecycle for these firms for future research.
} 
of falling distance-to-default: for example, a firm that we classify as being in distress in 1995 (the commencement of our sample period) will have had a declining distance-to-default in both 1994 and 1995. This approach is analogous to that of a climber approaching a precipice: she hopes her companions will pull her back to safety. In the same way, a firm approaching its default point should come under pressure from stakeholders to take action to reverse its direction.

Table 1 presents the count of the number of distress firms and non-distress firms by the four lifecycle categories. ${ }^{3}$ Figure 1 illustrates the pattern of distressed firms across the sample period, showing a sharp increase in distress firms during three events: the 1997/1998 Asian Financial Crisis, the 2001/2002 tech-stock crash, and a spike during the 2007/2008 Global Financial Crisis.

[TABLE 1 ABOUT HERE]

[FIGURE 1 ABOUT HERE]

\subsection{Types of restructuring strategies}

We investigate the four types of restructuring strategies, managerial, operational, asset, and financial.

A firm is defined as engaging in managerial restructuring if it has replaced one of its top tier management: the Chief Executive Officer (CEO) or Managing Director (MD). We obtained information on CEO or MD replacement from the S\&P Executive Compensation database. As do Atanassov and Kim (2009), we consider managerial restructuring has occurred if a CEO or MD changes during the distress period (i.e., year t). The reason for leaving and age of the management are examined to ensure that a replacement is not due to death, illness, or retirement.

\footnotetext{
${ }^{3}$ We remove outliers by trimming our sample at $5 \%$, using Ln(Total Assets).
} 
Operational and asset restructuring are generally the first broad strategies firms undertake. We look at a number of such strategies, including reducing investments, reducing the cost of goods sold (GOGS), laying off employees and selling off assets. As in Kang and Shivdasani (1997), the variable INV (ASSETS) denotes a strategy to reduce investments (fixed assets) and takes a value of 1 (zero otherwise) if a firm's investing activities, proxied by COMPUSTAT item IVNCF (total (net) property, plant and equipment), falls more than 15 percent between year $\mathrm{t}-1$ and year $\mathrm{t}$ or year $\mathrm{t}+1$, where year $\mathrm{t}$ is the observed firm-year; for distress firms, it is also the year of distress. For the strategy of reducing COGS, we follow Atanassov and Kim (2009), who deem this to be implemented if a firm's COGS (scaled by Sales) is above the industry median in year $\mathrm{t}-1$ but falls to the bottom quartile in year $\mathrm{t}$ or year $\mathrm{t}+1$. A firm is deemed to have undertaken a strategy of laying off its employees if it has a more than 20 percent fall in the number of employees between year $t-1$ and year $t$ or $t+1$ (Denis and Kruse, 2000).

Financial restructuring typically includes cutting or omitting dividends, issuing new security and exchanging debt for equity. Following Chen and Zhang (1998), we deem a firm to have undertaken financial restructuring if it experiences more than a 25 percent decrease in the total dividends paid between year $\mathrm{t}-1$ and year $\mathrm{t}$ or $\mathrm{t}+1$. We define a firm to have issued equity (debt) when the firm's net equity (net debt) exceeds 5 percent of the book value of its total assets at year $\mathrm{t}$ (Hovakimian, Hovakimian and Tehranian, 2004). Table 2 presents the definitions of the variables discussed above.

[TABLE 2 ABOUT HERE]

\section{LIFECYCLE THEORY, DISTRESS FIRMS AND RESTRUCTURING STRATEGIES}

As firms in the birth stage have highly centralized power structures (Miller and Friesen 1984), it is likely that the managers are also the owners. This suggests that there will be little 
external pressure for a change in management when such firms are in distress; firms in the birth stage are not likely to engage in managerial restructuring. However, as a firm moves along its lifecycle, its business structure becomes more complex, and it becomes more likely existing management may be replaced. We begin our analysis by examining if firms in the earlier lifecycle stages are less (or more) likely to use managerial restructuring than firms in later stages, by running a panel logistic regression with random effects. We utilize bootstrapped standard errors to ensure that the inferences we make about the estimated coefficients are robust; it is well known that the bootstrap results in consistent estimates of test statistics. ${ }^{4}$ The dependent variable takes on the value of 1 if the CEO/MD has left the firm and zero otherwise.

$$
\begin{aligned}
& \text { CEO }_{i t}=\alpha_{1}+\alpha_{2} \text { BIRTH }_{i t}+\alpha_{3} \text { GROWTH }_{i t}+\alpha_{4} \text { MATURE }_{i t}+\alpha_{5} \text { FD }_{i t} \\
& +\alpha_{6} \text { BIRTH }^{*} \text { FD }_{i t}+\alpha_{7} \text { GROWTH } * F D_{i t}+\alpha_{8} \text { MATURE }^{*} F D_{i t}+\alpha_{9} \text { Tobins }_{i t} \\
& +\alpha_{10} \text { LnTotalAssets }_{i t}+\alpha_{11} \text { Institutional }_{i t}+\alpha_{12} \text { Volatility }_{i t}+\alpha_{13} \operatorname{Re} \text { turn }_{i t}+\alpha_{14} \text { Leverage }_{i t} \\
& \alpha_{15} \text { CashFlow }_{i t}+\varepsilon_{i}
\end{aligned}
$$

BIRTH, GROWTH and MATURE are the lifecycle dummies that take the value 1 for the respective lifecycle stages and zero otherwise. FD is the dummy variable for a distress firm and takes the value of 1 if the firm is in distress and zero otherwise. We have also added a number of control variables: TobinsQ, LnTotalAssets, Institutional, Volatility, Return, Leverage and CashFlow. The first two are included to control for growth opportunities and firm size. ${ }^{5,6}$ Kang and Shivdasani (1997) find a positive relationship between outside blockholders and the probability of top management turnover in Japanese firms. Bethel and Liebeskind (1993) find that the prominence of managerial restructuring in the US in the late

\footnotetext{
${ }^{4}$ See Efron and Tibshirani (1993) for a discussion of bootstrapping.

${ }^{5}$ As mentioned in Section 2, Moulton and Thomas (1993) find that firm size dominates all other variables in predicting successful completion of reorganization.

${ }^{6}$ Our referee highlighted how intangible assets, as a proportion of total assets, might also affect the strategy employed by firms: for example, a growth firm may find it difficult to replace management whose special knowledge of key intangible assets is essential. Total assets per se may be a poor proxy for this effect, as firms cannot recognize internally generated intangibles. Further, our study spans a significant change in the way intangible assets are recognized (Financial Accounting Standards Board 2001a, 2001b). We leave the detailed consideration of any effect for future research.
} 
1980s was a result of outside pressure by blockholders. As we expect that birth and growth firms are less likely to have outside blockholders or to be influenced by external shareholder pressure since there is a close manager-owner connection, we include institutional ownership as a control against biased results for our sample firms. Shumway (2001) suggests that stock returns and the volatility of a firm's stock returns appear to be unambiguous proxies for the probability of the firm's future failure; we include both as our risk-proxy variables. The theoretical frameworks by Black-Sholes-Merton (based on perfect market assumptions) demonstrate that, all else remaining constant, a firm's risk of failure increases monotonically with leverage (Black and Scholes, 1973; Merton, 1974); we therefore include leverage in our equations. Finally, we control for a firm's cash flow, following Fitzpatrick and Ogden (2011) who find that net cash flow from operations is able to indicate financial distress of a firm. Table 3 presents the results for Equation 1.

\section{[TABLE 3 ABOUT HERE]}

In Table 3 we find that distressed firms are more likely to change their CEO: the coefficient of FD is 0.0057 and significant. The lifecycle dummy variables, BIRTH, GROWTH, MATURE, are also significant, indicating that, in comparison with firms in decline (the base case for this and our subsequent analyses), firms are more likely to change their CEO at any time. The interactions of the lifecycle dummy variables with the financial distress dummy do not result in significant results. These findings suggest that the propensity for firms to change CEOs in times of distress bears no relationship to where they are in their lifecycle.

We next examine if lifecycle theory has an impact on the types of operational/asset restructuring strategies undertaken by firms, with the following logistic regression with bootstrapped standard errors: 
Re structuring ${ }_{i t}=\alpha_{1}+\alpha_{2}$ BIRTH $_{i t}+\alpha_{3}$ GROWTH $_{i t}+\alpha_{4}$ MATURE $_{i t}+\alpha_{5} F D_{i t}$

$+\alpha_{6}$ BIRTH $^{*} F D_{i t}+\alpha_{7}$ GROWTH $* F D_{i t}+\alpha_{8}$ MATURE $* F D_{i t}+\alpha_{9}$ Tobins $_{i t}$

$+\alpha_{10}$ LnTotalAssets $_{i t}+\alpha_{11}$ Institutional $_{i t}+\alpha_{12}$ Volatility $_{i t}+\alpha_{13}$ Re $_{\text {turn }}+\alpha_{14}$ Leverage $_{i t}$

$+\alpha_{15}$ CashFlow $_{i t}+\varepsilon_{i}$

We run the regression in Equation 2 four times, replacing the dependent variable each time with the various operational/asset restructuring strategies: (1) reducing investing activities (INV), (2) reducing cost of goods sold (COGS), (3) laying off employees (EMP) and (4) asset sales (ASSETS) where INV, COGS and EMP are the various types of operational restructuring strategies. If a firm engages in operational restructuring it may choose at least one of these strategies. To account for multiple strategies concurrently, we run a fifth regression with a dependent variable, OPS, which takes a value of 1 if at least one of the operational restructuring strategies has been employed and zero otherwise. Table 4 reports our findings.

\section{[TABLE 4 ABOUT HERE]}

While we focus on the interaction terms, it is worth noting that distress makes operational restructuring (saving by reducing COGS) more likely to take place; the distress dummy, FD, is positive and significant in all equations with the exception of COGS. Contraction policies such as reducing COGS may not be viable for a firm in distress; it may be more practical for them to adopt expansion policies and aggressively increase their sales (John, Lang and Netter, 1992).

We also find that birth firms in distress are less likely to reduce COGS than decline firms in distress. The coefficient of the interaction of BIRTH and FD is -0.0220 and is statistically significant at the 5 percent level. Logistic regressions allow the calculation of odds ratios. ${ }^{7}$ We do not report odds ratios in the tables but the odds ratios associated with the

\footnotetext{
${ }^{7}$ When a logistic regression is calculated, the regression coefficient (b1) is the estimated increase in the log odds of the outcome per unit increase in the value of the exposure. In other words, the exponential function of the regression coefficient $\left(e^{b l}\right)$ is the odds ratio associated with a one-unit increase in the exposure. Hene, the odds
} 
independent variables are supportive of the conclusions we draw on the basis of the estimated coefficients. The odds ratio for the interaction of BIRTH and FD of 0.1916 is less than 1 , indicating that, compared to decline firms in distress, the odds of birth firms in distress not engaging in reducing COGS increase by a factor of 5.2192 (all other factors being equal). When we examine the regression result for firms that engage in other operational restructuring, we find that birth, growth and mature firms are all likely to reduce the number of employees when they are in distress. In Column 3, the coefficients of the interactions of these lifecycle dummies with FD are 0.0980, 0.0496 and 0.0477 respectively. The respective odds ratios of $1.5497,1.2733$ and 1.4318 , indicate that, compared with decline firms in distress, the odds of birth, growth and mature firms in distress engaging in employee restructuring increase by the same factor (all other factors being equal). Reduction of employees, described as "belt-tightening" or "fire-fighting", aims to produce a "quick-win", either to stabilize finances in the short term until more complex strategies are devised or to improve cash flow quickly (Bibeault, 1982; Hambrick and Schecter, 1983; Sudarsanam and Lai, 2001). Compared to decline firms in distress, distressed firms in the earlier lifecycle stages are more likely to retrench employees. This strategy can be quickly implemented, may have an almost immediate effect, and generally requires little or no capital or resource outlay (Hofer, 1980; Robbins and Pearce, 1992). Distressed decline firms, on the other hand, are forced to be risk averse in their strategies as they cannot sustain potential losses, and employee reduction restructuring carries risks that morale and commitment will be reduced. This may increase staff turnover, including key employees who are essential if the firm is to turn around (Barker and Mone, 1994).

ratio represents the odds that an outcome will occur given a particular exposure, compared to the odds of the outcome occurring in the absence of that exposure (Szumilas, 2010). 
In Column 4 of Table 5 we find that the FD coefficient of 0.1080 is statistically significant at the 1 percent level; firms in distress are likely to engage in at least one of the operational restructuring strategies. However, we do not find significant results for the interactions of the lifecycle dummies and FD.

Lifecycle theory suggests that younger firms are typically small, with a limited range of product lines, and focused on expansion: they are unlikely to engage in asset restructuring. In Column 5 of Table 4, we find that younger firms in distress are no different from the base case (decline firms) in their resort to asset restructuring in times of distress (the coefficients of the interactions of BIRTH and FD and GROWTH and FD are not significant). Birth, growth and decline firms in distress are therefore likely to retain their assets, to collect as much funds from existing operations as possible, and their creditors are likely to place restrictions on asset disposal for fear of being unable to recover debts. Mature firms, on the other hand, are more likely to engage in asset restructuring: the coefficient of the interaction firm is 0.0226 and significant at the 10 percent level. This behavior is consistent with the notion that these mature firms are focused on efficiency (Miller and Friesen 1984) and can redeploy resources from the sale of underperforming businesses to better ends (Atanassov and Kim 2009).

Finally, to examine if distress firms in the earlier lifecycle stages are less (or more) likely to use financial restructuring strategies than firms in the later stages, we run the following logistic regression with bootstrapped standard errors:

$$
\begin{aligned}
& \text { Re } \text { structuring }_{i t}=\alpha_{1}+\alpha_{2} \text { BIRTH }_{i t}+\alpha_{3} \text { GROWTH }_{i t}+\alpha_{4} \text { MATURE }_{i t}+\alpha_{5} \text { FD }_{i t} \\
& +\alpha_{6} \text { BIRTH }^{*} F D_{i t}+\alpha_{7} \text { GROWTH }^{*} F D_{i t}+\alpha_{8} \text { MATURE }^{*} F D_{i t}+\alpha_{9} \text { Tobins }_{i t} \\
& +\alpha_{10} \text { LnTotalAssets }_{i t}+\alpha_{11} \text { Institutional }_{i t}+\alpha_{12} \text { Volatility }_{i t}+\alpha_{13} \text { Re } \text { turn }_{i t}+\alpha_{14} \text { Leverage }_{i t} \\
& +\alpha_{15} \text { CashFlow }_{i t}+\varepsilon_{i}
\end{aligned}
$$

We run the regression with three separate dependent variables: reduction of dividend (DIV), issuing of debt (NetDebt) and issuing of equity (NetEquity). As with operational restructuring, a firm engaged in financial restructuring may choose either one or a 
combination of strategies; to account for this we also run a fourth regression with a FIN dependent variable. FIN takes a value of one if at least one of the financial restructuring strategies has been employed, and zero otherwise. Table 5 presents the results for the financial restructuring. As we noted when discussing Table 4, we find that the distress dummy, FD, is positive and significant in all equations: distress makes it more likely that firms will engage in financial restructuring.

\section{[TABLE 5 ABOUT HERE]}

We find persuasive evidence supporting the lifecycle theory. Birth, growth and mature firms in distress are all unlikely to reduce dividends. The coefficients of the interactions of these lifecycle dummies with FD are $-0.0850,-0.0489$ and -0.0411 respectively. The respective odd ratios of $0.3951,0.6953$ and 0.7356 are all less than 1 , indicating that, compared with decline firms in distress, the odds of birth, growth and mature firms in distress not engaging in reducing dividends increase by factors of $2.5310,1.4382$ and 1.3594 respectively, all other factors being equal. This finding suggests that decline firms in distress have a propensity to reduce dividends to preserve funds for keeping themselves afloat (Mueller 1972; DeAngelo and DeAngelo 1990).

In Column 2 of Table 5, we find that the interaction of BIRTH and FD is -0.0602 and significant at the 5 percent level. Compared with firms at other stages of the lifecycle, those in the birth stage are less likely to issue debt. They are in the initial stages of operation, often struggling to remain viable against competition from older, more established firms; they tend to have an entrepreneurial focus with a risk-taking strategic approach; their future cash flows are uncertain: the market tends to consider such firms risky (Lubos and Peitro, 2003; Miller and Friesen, 1984; Pastor and Veronesi, 2003). While birth firms may require debt liquidity to survive the distress, given their more risky nature, these qualities means that lenders of funds are unlikely to lend to them, so making it difficult for them to issue debts. 
In Column 3 of Table 5, we find that firms in distress are less likely to raise funding through issuing equity. The FD coefficient of -0.0138 is significant at the 1 percent level. This finding contradicts the pecking order hypothesis that firms will resort to raising external funds through the issuance of equity when in distress; and when we analyze the interaction variables, we find that distressed mature firms are less likely to raise equity than firms at other stages of their lifecycle. The coefficient of the interaction of MATURE and FD is 0.0167 and is significant at the 5 percent level; the odds of mature firms in distress not issuing equity increase by a factor of 1.3349 . One explanation for distressed mature firms not raising new equity (relative to firms in other lifecycle stages) is that they are likely to have fewer investment opportunities (Mueller, 1972). Investors may also avoid investing in them.

In Column 4 of Table 5, we examine FIN, a variable that takes a value of one if at least one of the financial restructuring strategies has been employed and zero otherwise. Firms in distress are likely to employ financial restructuring strategies; the coefficient of FD is 0.1537 and is significant at the 1 percent level. However, the coefficients of the interactions of these lifecycle dummies with FD for birth, growth and mature firms are $-0.1101,-0.0449$ and 0.028 and the odds ratios are $0.5859,0.8223$ and 0.7337 : compared with decline firms in distress, the odds of younger firms not engaging in financial restructuring strategies increase by factors of $1.7068,1.2161$ and 1.3630 . Decline firms in distress are likely to be aggressive in financial restructuring as shrinking markets, drop in demand and lack of innovation contribute to ever-declining sales.

\section{RESTRUCTURING EFFECTIVENESS}

In the preceding section we provide some evidence that is consistent with the lifecycle theory. Depending on their stage of the lifecycle, firms in distress prefer certain restructuring strategies. However, the ability to engage in a strategy does not necessarily ensure a successful turnaround. Firms may continue to falter and may eventually file for bankruptcy. 
For our sample of firms in distress only, we examine the effectiveness of restructuring strategies. In order to be consistent with our previous definition of a distressed firm, we define a "recovered" firm as one that increases its distance-to-default in two consecutive years: for example, a distress firm in 1995 is deemed to have turned around if its distance-todefault increases in both 1996 and 1997. We present a simple summary of the strategies firms undertake and their relationship with recovery in Table 6 . There is prima facie evidence that reducing dividends, selling assets and reducing employees have a slightly higher association with recovery. However, in order to rigorously test the relationships of strategies to recovery, we follow the procedure we have used previously in the paper and run the following logistic regression with bootstrapped standard errors to examine the effectiveness of restructuring strategies in distress firms:

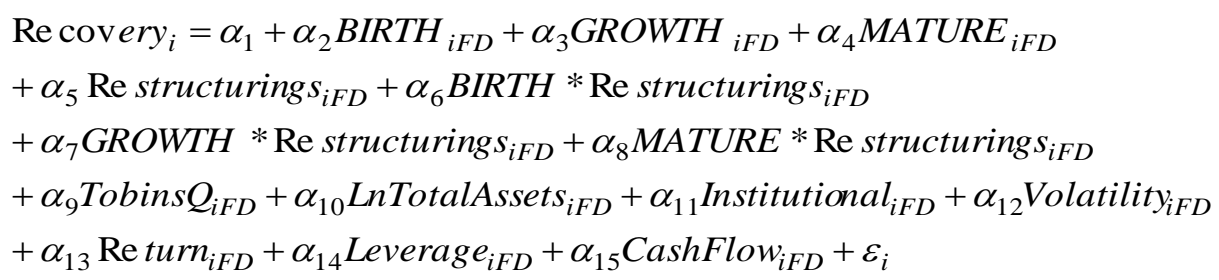

The dependent variable, Recovery, takes the value 1 if a distress firm recovers and zero otherwise. The independent variable, Restructurings, represents managerial, operational/asset and financial restructuring strategies, examined in the previous section. Table 7 presents the results on the effectiveness of restructuring strategies.

\section{[TABLE 6 ABOUT HERE]}

\section{[TABLE 7 ABOUT HERE]}

When examining the effectiveness of managerial restructuring strategy in Column 1 of Table 7, we find that birth firms are more likely to recover if they replace their incompetent management. The coefficient of 0.4472 is statistically significant at the 1 percent level. Compared with older firms, birth firms are in their infancy and commencing their business 
operations. Their business structure and operations will be less complex and it may be relatively easy for a new management team to turn the company around.

We next examine the effectiveness of operational restructuring strategies in Columns 2, 3 and 4 of Table 7. Operational restructuring strategies are primarily a short-term "fix", and both Barker and Duhaime (1997) and Denis and Kruse (2000) suggest that operational restructuring strategies are ineffectual. Confirming this notion, there are only two significant results for operational restructuring strategies. In Column 2, the coefficient for RESTRUCTURING of 0.0578 is significant at the 1 percent level; firms in distress that engaged in investment reduction increase their chances of survival. However, there is no difference across the different stage of corporate lifecycles. There is also no relationship between firms in distress that undertook reduction of COGS and employees and the route to recovery. In Column 3 we find that the statistically significant interaction of MATURE and COGS is consistent with past studies. Boyne and Meier (2009), for example, present evidence that firms are unsuccessful in turnaround efforts when they over-pursue cost efficiencies, and may actually exacerbate the decline.

In Column 5 of Table 7, we also find that asset restructuring strategy is also not an effective restructuring strategy (ASSETS, and the interaction of ASSETS with the lifecycle dummies, are insignificant). When we analyze the effectiveness of the financial restructuring strategies in Columns 6, 7 and 8 of Table 7, we find that the coefficient for birth firms that cut or omit dividends is -0.3108 (statistically significant at the 1 percent level): cutting or omitting dividends will not revive birth firms in distress; nor is there evidence that other financial restructuring strategies are effective. The findings regarding debt and equity (Columns 7 and 8) are instructive. Pecking order theory predicts that, when precluded from other alternatives, a firm has no option but to issue equity, especially when in financial distress. However, adverse selection by buyers means that the firm has to issue the new 
equity at heavily discounted prices, and the cost of doing this may be too great to provide enough cash flow to reverse the distress.

So far we have explored the effectiveness of the four restructuring strategies as if they were mutually exclusive, but distress firms may well adopt multiple restructuring strategies concurrently. We therefore extend our effectiveness analysis to include circumstances where a distress firm adopts more than one type of strategy. We run the following logistic regression with bootstrapped standard errors to examine the success of recovering from financial distress when firms take on more than one strategy:

$$
\begin{aligned}
& \text { Re covery } i=\alpha_{1}+\alpha_{2} \text { BIRTH }_{i F D}+\alpha_{3} \text { GROWTH }_{i F D}+\alpha_{4} \text { MATURE }_{i F D} \\
& +\alpha_{5} \text { NumStrategies }_{i F D}+\alpha_{6} \text { BIRTH }^{*} \text { NumStrategies }_{i F D} \\
& +\alpha_{7} \text { GROWTH }^{*} \text { NumStrategies }_{i F D}+\alpha_{8} \text { MATURE }^{*} \text { NumStrategies }_{i F D} \\
& +\alpha_{9} \text { Tobins }_{i F D}+\alpha_{10} \text { LnTotalAssets }_{i F D}+\alpha_{11} \text { Institutional }_{i F D}+\alpha_{12} \text { Volatility }_{i F D} \\
& +\alpha_{13} \text { Re } \text { turn }_{i F D}+\alpha_{14} \text { Leverage }_{i F D}+\alpha_{15} \text { CashFlow }_{i F D}+\varepsilon_{i}
\end{aligned}
$$

There are eight possible recovery strategies under the managerial, operational, assets and financial restructuring. We run four separate regressions to examine the effectiveness of a distress firm undertaking at least two, three, four, or five strategies concurrently. For each regression, the "NumStrategies" variable takes the value of 1 when the firm adapts the number of strategies under the regressed scenario, and zero otherwise. Table 8 presents the results.

\section{[TABLE 8 ABOUT HERE]}

In Columns 1 and 2 of Table 8, we find that NumStrategies is significant for all firms when at least 2 and 3 strategies are attempted. The coefficient of NumStrategies is 0.0486 (significant at the 5 percent level) in Column 1 when two or more strategies are undertaken. The coefficient of NumStrategies is 0.0554 (significant at the 10 percent level) in Column 2 when three or more strategies are undertaken. We do not find significance when four or more strategies are attempted (Columns 3 and 4). We also find that when five or more strategies are attempted (Column 4) by a distressed birth firm, the interacting coefficient is negative, - 
0.3659, and significant at the 10 percent level. This suggests that firms are less likely to recover from distress despite undertaking multiple restructuring strategies - that undertaking too many strategies is detrimental.

The analyses in Tables 7 and 8 provide some insight into the contribution of strategies, lifecycle and the interaction of lifecycle and strategies in recovery. The logistic regressions, as we have noted, facilitate the calculation of odds ratios. ${ }^{8}$ In Panel A of Table 9 we present the odds ratios associated with estimates presented for strategies, and the interaction of those strategies with the lifecycle dummy variables, that we reported in Table 7. In Panel B of Table 9 with we present the odds ratios associated with the estimates reported in Table 8. For all firms Panel A of Table 9 indicates that reducing investment activities (INV) and reducing dividends (DIV) have statistically significant positive associations with recovery; and altering capital structure by increasing debt (NetDebt) reduces the likelihood of recovery. In keeping with the results for birth firms reported in Table 7, in Panel A of Table 9 we find that there is a higher likelihood of recovery for birth who remove their CEO or who reduce their dividend ceteris paribus. Consistent with our findings in Table 8, undertaking at least two or at least three strategies is found to have a positive association with recovery but no association is found for four or more strategies.

\section{[TABLE 9 ABOUT HERE]}

\section{CONCLUSION}

When firms approach default, shareholders may pressure management to take action to turn the firm around. Creditors may also demand corrective measures, especially when debt covenants may be violated. While the choice of corrective measures is made by management, these may be constrained by the firm's stage in the corporate lifecycle.

\footnotetext{
${ }^{8}$ See footnote 7 for a short discussion of odds ratios.
} 
We examine the implications of the lifecycle theory on how distressed firms choose their restructuring strategies and find evidence that distress firms' recourse to different types of restructuring strategies is influenced by the stage of the lifecycle they are in. We find that firms in earlier stages of the lifecycle have a tendency to reduce their employees; mature firms are more likely to engage in asset restructuring. The influence of lifecycle is most pronounced in the choice of financial restructuring strategies such as reducing dividends or varying capital structures.

Even for those who are able to implement these strategies, there is no assurance that the strategies will be effective in turning the firm around. Our analyses suggest that reducing investment and dividends have a positive association with recovery for all firms regardless of where they are in the lifecycle. Increasing debt reduces the likelihood of recovery. There is also some evidence that the interaction of lifecycle and the choice of strategy is associated with recovery. We find it instructive that adopting less, rather than more, strategies, is associated with recovery. Adopting at least three strategies when confronting financial distress is associated with recovery. Adopting more than three strategies, however, has no significant association with recovery.

\section{Acknowledgments}

SzeKee Koh and Millicent Chang gratefully acknowledge the financial support provided by a UWA Business School Research Development Grant. Robert B. Durand is grateful for support received from the Curtin Business School publication support scheme. We also thank Ranjodh Singh for his valuable research assistance. We have benefited from comments made by delegates to the 2011 Australasian Finance and Banking Conference held in Sydney (Australia), the 2012 Mid-West Finance Association Annual meeting held in New Orleans (USA) and the 2012 Asian Finance Association Annual meeting held in Taipei 
(Taiwan). We also acknowledge the comments and positive contribution of the anonymous reviewer of this article and the managing editor (Jeffry Netter) for his comments. All remaining errors are ours. 


\section{References}

Adizes, I., 2004. Managing Corporate Lifecycles. 2nd edn, Adizes Institute.

Anthony, J., Ramesh K., 1992. Association Between Accounting Performance Measures And

Stock Prices: A Test Of The Lifecycle Hypothesis. Journal of Accounting and Economics 15, 203-227.

Asquith, P., Gertner, R., Scharfstein, D., 1994. Anatomy Of Financial Distress: An Examination Of Junk-Bond Issuers. The Quarterly Journal of Economics 109, 625-658.

Atanassov, J., Kim, H., 2009. Labor And Corporate Governance: International Evidence From Restructuring Decisions. The Journal of Finance 64, 341-373.

Barker, V., Duhaime, I., 1997. Strategic Change In The Turnaround Process: Theory And Empirical Evidence. Strategic Management Journal 18, 13-38.

Barker, V., Mone, M., 1994. Retrenchment: Cause of Turnaround or Consequence of Decline?. Strategic Management Journal 15, 395-405.

Bethel, J., Liebeskind, J., 1993. The Effects Of Ownership Structure On Corporate Restructuring. Strategic Management Journal. 14, 15-31.

Bharath, S., Shumway, T., 2008. Forecasting Default with the Merton Distance to Default Model, Review of Financial Studies 21, 1339-1369.

Bibeault, D., 1982. Corporate Turnaround. McGraw Hill: New York.

Black, F, Scholes, M., 1973. The Pricing Of Options And Corporate Liabilities. Journal of Political Economy 81, 637-659.

Blinder, A., 2013. After the Music Stopped. Penguin: New York.

Boyne, G., Meier, K., 2009. Environmental Change, Human Resources and Organizational Turnaround. Journal of Management Studies 46, 835-863.

Brown, D., James, C., Mooradian, R., 1994. Asset Sales By Financially Distressed Firms. Journal of Corporate Finance 1, 233-257. 
Chen, N., Zhang, F., 1998. 'Risk And Return of Value Stocks', Journal of Business, 71, 50135

Chen, Y., Weston, F., Altman, E., 1995. Financial Distress And Restructuring Models. Financial Management 24, 57-75.

DeAngelo, H., DeAngelo, L., 1990. Dividend Policy And Financial Distress: An Empirical Investigation Of Troubled NYSE Firms. The Journal of Finance, 45, 1415-1431.

Denis, D., Kruse, T., 2000. Managerial Discipline And Corporate Restructuring Following Performance Declines. Journal of Financial Economics 55, 391-424.

Dickinson, V., 2011. Cash Flow Patterns As A Proxy For Firm Life Cycle. The Accounting Review 86, 1969-1994.

Efron, B., Tibshirani, R., 1993. An Introduction To The Bootstrap. New York: Chapman and Hall.

Fitzpatrick, J., Ogden, J., 2011. The Detection and Dynamics of Financial Distress. International Review of Finance 11, 87-121.

Financial Accounting Standards Board, 2001a. Statement of Financial Accounting Standards (SFAS) No. 141: Business Combinations. Norwalk, CT, Financial Accounting Standards Board.

Financial Accounting Standards Board, 2001b. Statement of Financial Accounting Standards (SFAS) No. 142: Goodwill and Other Intangible Assets. Norwalk, CT, Financial Accounting Standards Board.

Hambrick, D., Schecter, S., 1983. Turnaround Strategies for Mature Industrial Product Business Units. Academy of Management Journal 26, 231-248.

Hofer, C., 1980. Turnaround Strategies. Journal of Business Strategy 1, 19-31. 
Hovakimian, A., Hovakimian, G., Tehranian, H., 2004. Determinants Of Target Capital Structure: The Case Of Dual, Debt And Equity Issues. Journal of Financial Economics 71, 517-540.

Jensen, M., 1989. The Eclipse Of The Public Corporation. Harvard Business Review 5, 6174.

Kang, J.K., Shivdasani A., 1997. Corporate Restructuring During Performance Declines In Japan. Journal of Financial Economics 46, 510-546.

Merton, R., 1974. On The Pricing Of Corporate Debt: The Risk Structure of Interest Rates. Journal of Finance 29, 449-470.

Miller, D., Friesen, P., 1984. A Longitudinal Study Of The Corporate Life Cycle. Management Science 30, 1161-1183.

Moulton, W., Thomas, H., 1993. 'Bankruptcy As A Deliberate Strategy: Theoretical Considerations And Empirical Evidence. Strategic Management Journal 14, 125-135.

Mueller, D., 1972. A Life Cycle Theory Of The Firm. The Journal of Industrial Economics 20, 199-219.

Pashley, M., Philippatos, G., 1990. Voluntary Divestitures And Corporate Life-cycle: Some Empirical Evidence Applied Economics 22, 1181-1196.

Pastor, L., Veronesi, P., 2003. Stock Valuation And Learning About Profitability. The Journal of Finance 58, 1749-1989.

Pearce, J., Robbins, D., 1993. Toward Improved Theory And Research On Business Turnaround. Journal of Management 19, 613-637.

Robbins, D., Pearce, J., 1992. Turnaround: Retrenchment and Recovery. Strategic Management Journal 13, 287-309.

Shleifer, A, Vishny, R., 1992. Liquidation Values And Debt Capacity: A Market Equilibrium Approach. The Journal of Finance 47, 1343-1366. 
Shumway, T., 2001. Forecasting Bankruptcy More Accurately: A Simple Hazard Model. Journal of Business 74, 101-124

Sudarsanam, S., Lai, J., 2001. Corporate Financial Distress And Turnaround Strategies: An Empirical Analysis. British Journal of Management 12, 183-199.

Sundaram, R., Yermack, D., 2007. Pay Me Later: Inside Debt and Its Role in Managerial Compensation. Journal of Finance 62, 1551-1588.

Szumilas, M., 2010. Explainging Odds Ratios. Journal of the Canadian Academy of Child and Adolescent Psychiatry 19, 227-229

Thietart, R., Vivas, R., 1984. An Empirical Investigation Of Success Strategies For Businesses Along The Product Life Cycle. Management Science 30, 1405-1423.

Whitaker, R., 1999. The Early Stages Of Financial Distress. Journal of Economics and Finance 23, 123-132.

Wruck, K., 1990. Financial Distress, Reorganization, and Organizational Efficiency. Journal of Financial Economics 27, 419-444. 
Table 1

Breakdown of the number of distress firm-year observations and non-distress firm-year observations by the four lifecycle categories.

Distress Firms

Non-Distress Firms

Total

\begin{tabular}{lccc}
\hline Birth & 175 & 1311 & 1486 \\
Growth & 808 & 4484 & 5292 \\
Mature & 1486 & 6958 & 8444 \\
Decline & 2803 & 10322 & 13125 \\
Total & 5272 & 23075 & 28347 \\
\hline
\end{tabular}




\section{Table 2}

Definition of Variables.

Dependent Variables

$\mathrm{CEO}_{\text {it }}$

Dummy variable where it is equal to 1 if the CEO of the firm is replaced and zero otherwise.

$\mathrm{INV}_{\text {it }}$ Dummy variable where it is equal to 1 if the firm experiences more than $15 \%$ decrease in investment activities from year $t-1$ to year $t$ or $t+1$ and zero otherwise.

$\mathrm{COGS}_{\text {it }}$ Dummy variable where it is equal to 1 if the firm's [Cost of goods sold/Sales] is initially above the industry median at year t- 1 and falls to the bottom quartile of its industry in year $t$ or year $t+1$ and zero otherwise.

EMP $_{\text {it }} \quad$ Dummy variable where it is equal to 1 if the firm experiences more than $20 \%$ drop in the number of employees from year $\mathrm{t}-1$ to year $\mathrm{t}$ or $\mathrm{t}+1$ and zero otherwise.

ASSETS $_{\text {it }} \quad$ Dummy variable where it is equal to 1 if the firm experiences more than $15 \%$ drop in its total property, plant and equipment (net) from year $\mathrm{t}-1$ to year $\mathrm{t}$ or $\mathrm{t}+1$ and zero otherwise.

$\mathrm{DIV}_{\mathrm{it}} \quad$ Dummy variable where it is equal to 1 if the firm experiences more than $25 \%$ drop in its total dividends from year $\mathrm{t}-1$ to year $\mathrm{t}$ or $\mathrm{t}+1$ and zero otherwise.

NetDebt $_{i t} \quad$ Dummy variable where it is equal to 1 if Net Debt exceeds $5 \%$ of the book value of total asset at year $t$ or $t+1$ and zero otherwise. Net Debt is measured by Compustat item: DLTIS (Data 111) less DLTR (Data 114).

Net Equityit Dummy variable where it is equal to 1 if Net Equity exceeds 5\% of the book value of total asset at year $t$ or $t+1$ and zero otherwise. Net Equity is measured by Compustat item: SSTK (Data 108) less PRSTKC (Data 115) 
Table 2

Definition of Variables (con't).

Independent Variables

Tobin's $\mathrm{Q}_{\text {it }} \quad$ Market capitalization + Total Asset - Common/Ordinary Equity, scaled by total assets at year $\mathrm{t}$.

LnTotal Assets $\quad$ Natural logarithm of company i's total asset at year $\mathrm{t}$.

Institutional $_{\text {it }} \quad$ The proportion of shares held by institutional investors reported in file s13 at year t.

Volatilityit Standard deviation of the monthly stock returns of year $t$.

Return $_{\mathrm{it}} \quad$ Mean of the monthly stock returns of year $\mathrm{t}$.

Leverage $_{\text {it }} \quad$ The ratio of book value of long term debt divided by the value of the

firm at year t. The value of the firm is the sum of market capitalization and the book value of long term debt.

CashFlow $_{i t} \quad$ The ratio of net cash flow from operations divided by total assets at year t. 


\section{Table 3}

Management Restructuring: The dependent variable (CEO) takes the value of 1 when managerial restructuring occurred and zero otherwise. Birth takes the value of 1 if a firm is in this stage and zero otherwise. Growth takes the value of 1 if a firm is in this stage and zero otherwise. Mature takes the value of 1 if a firm is in this stage and zero otherwise. FD takes the value of 1 if a firm is in financial distress and zero otherwise. TobinsQ is measured by Market capitalization + Total Asset - Common/Ordinary Equity, scaled by total assets. LnTotalAssets is measured by $\mathrm{Ln}$ (Total Assets). Institutional is measured by the total share holdings held by institutional investors, scaled by the total outstanding shares. Volatility is the standard deviation of the monthly stock returns. Return is the mean of the monthly stock returns. Leverage is the ratio of the book value of long term debt divided by the value of the firm. CashFlow is the ratio of net cash flow from operations divided by total assets. The bootstrapped standard errors are in brackets. $* * *, * *$, and $*$ denote statistical significance at the $1 \%, 5 \%$ and $10 \%$ levels respectively.

\begin{tabular}{|c|c|}
\hline & CEO \\
\hline Intercept & $\begin{array}{l}-0.0138 * * * \\
(0.0040)\end{array}$ \\
\hline BIRTH & $\begin{array}{l}0.01142 * * * \\
(0.0040)\end{array}$ \\
\hline GROWTH & $\begin{array}{l}0.0088 * * * \\
(0.0030)\end{array}$ \\
\hline MATURE & $\begin{array}{l}0.0038^{*} \\
(0.0023)\end{array}$ \\
\hline FD & $\begin{array}{c}0.0057^{*} \\
(0.0032)\end{array}$ \\
\hline BIRTH*FD & $\begin{array}{c}-0.0058 \\
(0.0123)\end{array}$ \\
\hline GROWTH*FD & $\begin{array}{l}0.0041 \\
(0.0071)\end{array}$ \\
\hline MATURE *FD & $\begin{array}{l}0.0032 \\
(0.0053)\end{array}$ \\
\hline TOBIN'S Q & $\begin{array}{c}0.0007 * \\
(0.0004)\end{array}$ \\
\hline TOTAL ASSETS & $\begin{array}{c}0.0044 * * * \\
(0.0005)\end{array}$ \\
\hline INSTITUTIONAL & $\begin{array}{l}0.0002 \\
(0.0001)\end{array}$ \\
\hline VOLATILITY & $\begin{array}{l}0.0029 \\
(0.0085)\end{array}$ \\
\hline RETURN & $\begin{array}{c}-0.0077 * * \\
(0.0 .0038)\end{array}$ \\
\hline LEVERAGE & $\begin{array}{l}-0.0001 \\
(0.0001)\end{array}$ \\
\hline CASHFLOW & $\begin{array}{l}0.0007 \\
(0.0075)\end{array}$ \\
\hline$\chi^{2}$ & $116.56^{* * *}$ \\
\hline
\end{tabular}




\section{Table 4}

Operational restructuring/asset restructuring: The dependent variable (Restructuring) takes the value of 1 when operational (asset) restructuring occurred and zero otherwise.

Restructuring includes reducing investing activities (INV), reducing the cost of goods sold (COGS), laying off employees (EMP) and asset sales (ASSETS). The dependent variable "OPS" takes the value of 1 when at least one type of operational restructuring occurred and zero otherwise. Definitions of restructuring are in Table 2. Birth takes the value of 1 if a firm is in this stage and zero otherwise. Growth takes the value of 1 if a firm is in this stage and zero otherwise. Mature takes the value of 1 if a firm is in this stage and zero otherwise. FD takes the value of 1 if a firm is in financial distress and zero otherwise. TobinsQ is measured by (Market capitalization) + Total Asset - Common/Ordinary Equity, scaled by total assets. LnTotalAssets is measured by $\operatorname{Ln}$ (Total Assets). Institutional is measured by the total share holdings held by institutional investors, scaled by the total outstanding shares. Volatility is the standard deviation of the monthly stock returns. Return is the mean of the monthly stock returns. Leverage is the ratio of the book value of long term debt divided by the value of the firm. CashFlow is the ratio of net cash flow from operations divided by total assets. The bootstrapped standard errors are in brackets. ${ }^{* *}, * *$, and $*$ denote statistical significance at the $1 \%, 5 \%$ and $10 \%$ levels respectively.

\begin{tabular}{|c|c|c|c|c|c|}
\hline & (1) & (2) & (3) & (4) & $(5)$ \\
\hline & INV & COGS & EMP & OPS & ASSETS \\
\hline \multirow[t]{2}{*}{$\mathrm{C}$} & $0.6880 * * *$ & $0.0122 * *$ & $0.2606^{* * * *}$ & $0.7182 * * *$ & $0.3545 * * *$ \\
\hline & $(0.0164)$ & $(0.0055)$ & $(0.01172)$ & $(0.0164)$ & $(0.0153)$ \\
\hline \multirow[t]{2}{*}{ BIRTH } & $0.0577 * * *$ & $0.0135 * *$ & 0.0133 & $0.0815 * * *$ & $0.0970 * * *$ \\
\hline & $(0.0141)$ & $(0.0058)$ & $(0.0124)$ & $(0.0136)$ & $(0.0142)$ \\
\hline \multirow[t]{2}{*}{ GROWTH } & $0.0279 * * *$ & $0.0095 * * *$ & -0.0078 & $0.0307 * * *$ & $0.0547 * * *$ \\
\hline & $(0.0091)$ & $(0.0030)$ & $(0.0066)$ & $(0.0094)$ & $(0.0078)$ \\
\hline \multirow[t]{2}{*}{ MATURE } & 0.0018 & 0.0033 & -0.0074 & 0.0045 & $0.0285 * * *$ \\
\hline & $(0.0080)$ & $(0.0021)$ & $(0.0054)$ & $(0.0080)$ & $(0.0061)$ \\
\hline \multirow[t]{2}{*}{ FD } & $0.1087 * * *$ & -0.0009 & $0.0226 * * *$ & $0.1080 * * *$ & $0.0306 * * *$ \\
\hline & $(0.0099)$ & $(0.0025)$ & $(0.0066)$ & $(0.0098)$ & $(0.0069)$ \\
\hline \multirow[t]{2}{*}{ BIRTH*FD } & -0.0533 & $-0.0220 * *$ & $0.0980 * * *$ & -0.0508 & -0.0260 \\
\hline & $(0.0334)$ & $(0.0093)$ & $(0.0340)$ & $(0.0314)$ & $(0.0351)$ \\
\hline \multirow[t]{2}{*}{ GROWTH*FD } & 0.0181 & -0.0013 & $0.0496 * * *$ & 0.0125 & 0.0210 \\
\hline & $(0.0182)$ & $(0.0057)$ & $(0.0156)$ & $(0.0183)$ & $(0.0178)$ \\
\hline \multirow[t]{2}{*}{ MATURE *FD } & -0.0171 & -0.0038 & $0.0477 * * *$ & -0.0238 & $0.0226 *$ \\
\hline & $(0.1587)$ & $(0.0043)$ & $(0.0124)$ & $(0.0158)$ & $(0.0126)$ \\
\hline \multirow[t]{2}{*}{ TOBIN'S Q } & $-0.0162 * * *$ & $0.0015 * *$ & $-0.0141 * * *$ & $-0.0170 * * *$ & $-0.0185 * * *$ \\
\hline & $(0.0022)$ & $(0.0007)$ & $(0.0015)$ & $(0.0021)$ & $(0.0020)$ \\
\hline \multirow[t]{2}{*}{ TOTAL ASSETS } & $-0.0139 * * *$ & -0.0003 & $-0.0195 * * *$ & $-0.0153 * * *$ & $-0.0302 * * *$ \\
\hline & $(0.0020)$ & $(0.0007)$ & $(0.0014)$ & $(0.0020)$ & $(0.0017)$ \\
\hline \multirow[t]{2}{*}{ INSTITUTIONAL } & 0.0002 & -0.0001 & -0.0001 & 0.0003 & -0.0001 \\
\hline & $(0.0012)$ & $(0.0001)$ & $(0.0003)$ & $(0.0011)$ & $(0.0003)$ \\
\hline \multirow[t]{2}{*}{ VOLATILITY } & $0.3143 * * *$ & $0.0467 * * *$ & $0.1930 * * *$ & $0.3475 * * *$ & $0.3758 * * *$ \\
\hline & $(0.0436)$ & $(0.0116)$ & $(0.0302)$ & $(0.0463)$ & $(0.0489)$ \\
\hline \multirow[t]{2}{*}{ RETURN } & $-0.1208 * * *$ & -0.0015 & $-0.0784 * * *$ & $-0.1321 * *$ & $-0.1034 * * *$ \\
\hline & $(0.0426)$ & $(0.0041)$ & $(0.0229)$ & $(0.0517)$ & $(0.0381)$ \\
\hline \multirow[t]{2}{*}{ LEVERAGE } & -0.0006 & 0.0001 & -0.0006 & -0.0006 & 0.0001 \\
\hline & $(0.0008)$ & $(0.0001)$ & $(0.0005)$ & $(0.0008)$ & $(0.0007)$ \\
\hline \multirow[t]{2}{*}{ CASHFLOW } & $-0.3013 * * *$ & $-0.0628 * * *$ & $-0.2481 * * *$ & $-0.3276 * * *$ & $-0.3286 * * *$ \\
\hline & $(0.0229)$ & $(0.0132)$ & $(0.0231)$ & $(0.0209)$ & $(0.0251)$ \\
\hline$\chi^{2}$ & $835.32 * * *$ & $75.42 * * *$ & $719.94 * * *$ & $1026.74 * * *$ & $1278.61 * * *$ \\
\hline
\end{tabular}




\section{Table 5}

Financial restructuring: The dependent variable (Restructuring) takes the value of 1 when financial restructuring occurred and zero otherwise. Restructuring includes dividend cuts (DIV), issue of debt (NetDebt) and issue of equity (NetEquity). The dependent variable "FIN" takes the value of 1 when at least one type of financial restructuring occurred and zero otherwise. Definitions of the restructurings are in Table 2. Birth takes the value of 1 if a firm is in this stage and zero otherwise. Growth takes the value of 1 if a firm is in this stage and zero otherwise. Mature takes the value of 1 if a firm is in this stage and zero otherwise. FD takes the value of 1 if a firm is in financial distress and zero otherwise. TobinsQ is measured by (Market capitalization) + Total Asset - Common/Ordinary Equity, scaled by total assets. Total Assets is measured by Ln(Total Assets). Institutional is measured by the total shareholdings held by institutional investors, scaled by the total outstanding shares. Volatility is the standard deviation of the monthly stock returns. Return is the mean of the monthly stock returns. Leverage is the ratio of the book value of long term debt divided by the value of the firm. CashFlow is the ratio of net cash flow from operations divided by total assets. The bootstrapped standard errors are in brackets. $* * *, * *$, and $*$ denote statistical significance at the $1 \%, 5 \%$ and $10 \%$ levels respectively.

\begin{tabular}{|c|c|c|c|c|}
\hline & $\begin{array}{l}\text { (1) } \\
\text { DIV }\end{array}$ & $\begin{array}{l}\text { (2) } \\
\text { NetDebt }\end{array}$ & $\begin{array}{l}\text { (3) } \\
\text { NetEquity }\end{array}$ & $\begin{array}{l}\text { (4) } \\
\text { FIN }\end{array}$ \\
\hline \multirow[t]{2}{*}{ C } & $0.0697 * * *$ & $0.0899 * * *$ & $0.1382 * * *$ & $0.2594 * * *$ \\
\hline & (0.0110)11 & $(0.01155)$ & $(0.0120)$ & $(0.0160)$ \\
\hline \multirow[t]{2}{*}{ BIRTH } & $-0.0331 * * *$ & $-0.0393 * * *$ & 0.0136 & $-0.0466 * * *$ \\
\hline & (0.0094) & $(0.0098)$ & $(0.0102)$ & $(0.0147)$ \\
\hline \multirow[t]{2}{*}{ GROWTH } & $-0.0426 * * *$ & $-0.0173 * * *$ & -0.0033 & $-0.0520 * * *$ \\
\hline & $(0.0063)$ & $(0.0064)$ & $(0.0054)$ & $(0.0085)$ \\
\hline \multirow[t]{2}{*}{ MATURE } & $-0.0274 * * *$ & -0.0040 & -0.0022 & $-0.0283 * * *$ \\
\hline & $(0.0051)$ & $(0.0059)$ & $(0.0042)$ & $(0.0071)$ \\
\hline \multirow[t]{2}{*}{ FD } & $0.0722 * * *$ & $0.1228 * * *$ & $-0.0138 * * *$ & $0.1537 * * *$ \\
\hline & $(0.0074)$ & $(0.0083)$ & $(0.0046)$ & $(0.0099)$ \\
\hline \multirow[t]{2}{*}{ BIRTH*FD } & $-0.0850 * * *$ & $-0.0602 * *$ & 0.0230 & $-0.1101 * * *$ \\
\hline & $(0.0228)$ & $(0.0274)$ & $(0.0256)$ & $(0.0367)$ \\
\hline \multirow[t]{2}{*}{ GROWTH*FD } & $-0.0489 * * *$ & -0.0027 & -0.0037 & $-0.0449 * *$ \\
\hline & $(0.0128)$ & $(0.0171)$ & $(0.0111)$ & $(0.0200)$ \\
\hline \multirow[t]{2}{*}{ MATURE*FD } & $-0.0411^{* * *}$ & -0.0049 & $--0.0167 * *$ & $-0.0628 * * *$ \\
\hline & (0.0109) & $(0.0144)$ & $(0.0081)$ & (0.0159) \\
\hline \multirow{2}{*}{ TOBIN'S Q } & -0.0003 & $0.0032 * *$ & $0.0254 * * *$ & 0.0216 *** \\
\hline & (0.0017) & $(0.0013)$ & $(0.0024)$ & $(0.0023)$ \\
\hline \multirow[t]{2}{*}{ TOTAL ASSETS } & $0.0038 * * *$ & $0.0080 * * *$ & $-0.0139 * * *$ & -0.0010 \\
\hline & $(0.0013)$ & $(0.0014)$ & $(0.0013)$ & $(0.0019)$ \\
\hline \multirow[t]{2}{*}{ INSTITUTIONAL } & -0.0005 & $0.0012 *$ & -0.0001 & 0.0006 \\
\hline & $(0.0004)$ & $(0.0007)$ & $(0.0002)$ & $(0.0007)$ \\
\hline \multirow[t]{2}{*}{ VOLATILITY } & $0.1794 * * *$ & $-0.0663 * *$ & $0.1939 * * *$ & 0.2796 *** \\
\hline & $(0.0283)$ & $(0.0271)$ & $(0.0297)$ & $(0.0378)$ \\
\hline \multirow[t]{2}{*}{ RETURN } & $-0.0538 * *$ & $0.0696 * * *$ & $0.0493 * * *$ & $0.0554 * * *$ \\
\hline & $(0.0213)$ & $(0.0154)$ & $(0.0187)$ & $(0.0198)$ \\
\hline \multirow[t]{2}{*}{ LEVERAGE } & 0.0002 & 0.0001 & -0.0001 & 0.0002 \\
\hline & $(0.0004)$ & $(0.0004)$ & $(0.0001)$ & $(0.0006)$ \\
\hline \multirow[t]{2}{*}{ CASHFLOW } & $-0.0755^{* * *}$ & $-0.1816 * * *$ & $-0.3819 * * *$ & $-0.5208 * * *$ \\
\hline & $(0.0178)$ & $(0.0194)$ & $(0.0231)$ & $(0.0303)$ \\
\hline$\chi^{2}$ & $277.11 * * *$ & $563.25^{* * *}$ & 792.60 *** & 837.33 *** \\
\hline
\end{tabular}




\section{Table 6}

Restructuring strategies: This table presents numbers of firms choosing a strategy, (the column headed "chosen"), the number of firms that recover and the percentage of firms which recover for firms in each of the four lifecycle stages as well as all firms. A firm is considered as having "recovered" firm when it increases its distance-to-default in two consecutive years following a period of distress. The types of restructuring strategies are defined in Table 2.

\begin{tabular}{|c|c|c|c|c|c|c|c|c|c|c|c|c|c|c|c|}
\hline & \multicolumn{3}{|c|}{ Birth } & \multicolumn{3}{|c|}{ Growth } & \multicolumn{3}{|c|}{ Mature } & \multicolumn{3}{|c|}{ Decline } & \multicolumn{3}{|c|}{ Total } \\
\hline $\begin{array}{l}\text { Restructuring } \\
\text { Strategy }\end{array}$ & Chosen & Recovery & $\begin{array}{c}\text { Recovery } \\
(\%)\end{array}$ & Chosen & Recovery & $\begin{array}{l}\text { Recovery } \\
\text { (\%) }\end{array}$ & Chosen & Recovery & $\begin{array}{c}\text { Recovery } \\
(\%)\end{array}$ & Chosen & Recovery & $\begin{array}{c}\text { Recovery } \\
(\%)\end{array}$ & Chosen & Recovery & $\begin{array}{c}\text { Recovery } \\
(\%)\end{array}$ \\
\hline CEO & 4 & 3 & $75 \%$ & 24 & 6 & $25 \%$ & 39 & 11 & $28 \%$ & 67 & 20 & $30 \%$ & 134 & 40 & $30 \%$ \\
\hline INV & 111 & 29 & $26 \%$ & 553 & 207 & $37 \%$ & 896 & 312 & $35 \%$ & 1695 & 617 & $36 \%$ & 3255 & 1165 & $36 \%$ \\
\hline COGS & 0 & 0 & - & 13 & 3 & $23 \%$ & 17 & 3 & $18 \%$ & 34 & 16 & $47 \%$ & 64 & 22 & $34 \%$ \\
\hline EMP & 43 & 12 & $28 \%$ & 157 & 61 & $39 \%$ & 235 & 92 & $39 \%$ & 282 & 108 & $38 \%$ & 717 & 273 & $38 \%$ \\
\hline Assets & 48 & 20 & $42 \%$ & 219 & 91 & $42 \%$ & 307 & 111 & $36 \%$ & 362 & 136 & $38 \%$ & 936 & 358 & $38 \%$ \\
\hline Div & 12 & 1 & $8 \%$ & 68 & 26 & $38 \%$ & 142 & 53 & $37 \%$ & 442 & 186 & $42 \%$ & 664 & 266 & $40 \%$ \\
\hline NetDebts & 22 & 7 & $32 \%$ & 174 & 48 & $28 \%$ & 327 & 111 & $34 \%$ & 635 & 194 & $31 \%$ & 1158 & 360 & $31 \%$ \\
\hline NetEquity & 26 & 7 & $27 \%$ & 63 & 22 & $35 \%$ & 71 & 24 & $34 \%$ & 111 & 36 & $32 \%$ & 271 & 89 & $33 \%$ \\
\hline
\end{tabular}


Table 7

Effectiveness of the restructuring strategies: The dependent variable (Recovery) takes the value of 1 when a distress firm increases its distance-to-default in two consecutive years following the distress year, and zero otherwise. Birth takes the value of 1 if a firm is in this stage and zero otherwise. Growth takes the value of 1 if a firm is in this stage and zero otherwise. Mature takes the value of 1 if a firm is in this stage and zero otherwise. Restructuring includes managerial, operational/assets and financial restructuring. Definitions of restructuring are in Table 2. TobinsQ is measured by (Market capitalization) + Total Asset - Common/Ordinary Equity, scaled by total assets. TotalAssets is measured by $\operatorname{Ln}$ (Total Assets). Institutional is measured by the total share holdings held by institutional investors, scaled by the total outstanding shares. Volatility is the standard deviation of the monthly stock returns. Return is the mean of the monthly stock returns. Leverage is the ratio of the book value of long term debt divided by the value of the firm. CashFlow is the ratio of net cash flow from operations divided by total assets. The bootstrapped standard errors are in brackets. ***, **, and * denote statistical significance at the $1 \%, 5 \%$ and $10 \%$ levels respectively.

\begin{tabular}{|c|c|c|c|c|c|c|c|c|}
\hline & $\begin{array}{l}\text { (1) } \\
\text { CEO }\end{array}$ & $\begin{array}{l}\text { (2) } \\
\text { INV }\end{array}$ & $\begin{array}{l}\text { (3) } \\
\text { COGS }\end{array}$ & $\begin{array}{l}\text { (4) } \\
\text { EMP }\end{array}$ & $\begin{array}{l}\text { (5) } \\
\text { ASSETS }\end{array}$ & $\begin{array}{l}\text { (6) } \\
\text { DIV }\end{array}$ & $\begin{array}{l}\text { (7) } \\
\text { NetDebt }\end{array}$ & $\begin{array}{l}\text { (8) } \\
\text { NetEquity }\end{array}$ \\
\hline $\mathrm{C}$ & $\begin{array}{l}0.3307 * * * \\
(0.0392)\end{array}$ & $\begin{array}{l}0.2942 * * * \\
(0.0405)\end{array}$ & $\begin{array}{l}0.3350 \text { *** } \\
(0.0391)\end{array}$ & $\begin{array}{l}0.3244 * * * \\
(0.0371)\end{array}$ & $\begin{array}{l}0.3250 \text { *** } \\
(0.0380)\end{array}$ & $\begin{array}{l}0.3254 * * * \\
(0.0385)\end{array}$ & $\begin{array}{l}0.3425 * * * \\
(0.0377)\end{array}$ & $\begin{array}{l}0.3339 * * * \\
(0.0393)\end{array}$ \\
\hline BIRTH & $\begin{array}{l}-0.0638 \\
(0.0426)\end{array}$ & $\begin{array}{l}0.0683 \\
(0.0962)\end{array}$ & $\begin{array}{l}-0.0451 \\
(0.0438)\end{array}$ & $\begin{array}{l}-0.0232 \\
(0.0506)\end{array}$ & $\begin{array}{l}-0.0887 * \\
(0.0493)\end{array}$ & $\begin{array}{l}-0.0178 \\
(0.0449)\end{array}$ & $\begin{array}{l}-0.0722 \\
(0.0461)\end{array}$ & $\begin{array}{l}-0.0614 \\
(0.0473)\end{array}$ \\
\hline GROWTH & $\begin{array}{l}0.0131 \\
(0.0251)\end{array}$ & $\begin{array}{l}-0.0410 \\
(0.0436)\end{array}$ & $\begin{array}{l}0.0121 \\
(0.0233)\end{array}$ & $\begin{array}{l}0.0062 \\
(0.0254)\end{array}$ & $\begin{array}{l}-0.0098 \\
(0.0255)\end{array}$ & $\begin{array}{l}0.0211 \\
(0.0246)\end{array}$ & $\begin{array}{l}0.0190 \\
(0.0263)\end{array}$ & $\begin{array}{l}0.0060 \\
(0.0242)\end{array}$ \\
\hline MATURE & $\begin{array}{l}-0.0098 \\
(0.0192)\end{array}$ & $\begin{array}{l}0.0039 \\
(0.0307)\end{array}$ & $\begin{array}{l}-0.0057 \\
(0.0188)\end{array}$ & $\begin{array}{l}-0.0192 \\
(0.0200)\end{array}$ & $\begin{array}{l}-0.0119 \\
(0.0205)\end{array}$ & $\begin{array}{l}-0.0020 \\
(0.0195)\end{array}$ & $\begin{array}{l}-0.0241 \\
(0.0212)\end{array}$ & $\begin{array}{l}-0.0127 \\
(0.0193)\end{array}$ \\
\hline RESTRUCTURING & $\begin{array}{l}-0.0441 \\
(0.0601)\end{array}$ & $\begin{array}{l}0.0578 * * * \\
(0.0210)\end{array}$ & $\begin{array}{l}0.1512 \\
(0.1046)\end{array}$ & $\begin{array}{l}0.0276 \\
(0.0334)\end{array}$ & $\begin{array}{l}0.0273 \\
(0.0286)\end{array}$ & $\begin{array}{l}0.0736^{* * * *} \\
(0.0275)\end{array}$ & $\begin{array}{l}-0.0413^{*} \\
(0.0242)\end{array}$ & $\begin{array}{l}0.0100 \\
(0.0493)\end{array}$ \\
\hline BIRTH*RESTRUCTURING & $\begin{array}{l}0.4472 * \\
(0.2450)\end{array}$ & $\begin{array}{l}-0.1561 \\
(0.1000)\end{array}$ & Omitted & $\begin{array}{l}-0.0976 \\
(0.0837)\end{array}$ & $\begin{array}{l}0.1082 \\
(0.0901)\end{array}$ & $\begin{array}{l}-0.3108 * * * \\
(0.0892)\end{array}$ & $\begin{array}{l}0.1123 \\
(0.1048)\end{array}$ & $\begin{array}{l}0.0815 \\
(0.1089)\end{array}$ \\
\hline GROWTH*RESTRUCTURING & $\begin{array}{l}-0.0783 \\
(0.0975)\end{array}$ & $\begin{array}{l}0.0579 \\
(0.0483)\end{array}$ & $\begin{array}{l}-0.2484 \\
(0.1951)\end{array}$ & $\begin{array}{l}0.0151 \\
(0.0583)\end{array}$ & $\begin{array}{l}0.0601 \\
(0.0488)\end{array}$ & $\begin{array}{l}-0.0538 \\
(0.0710)\end{array}$ & $\begin{array}{l}-0.0363 \\
(0.0582)\end{array}$ & $\begin{array}{l}0.0743 \\
(0.0814)\end{array}$ \\
\hline MATURE*RESTRUCTURING & $\begin{array}{l}-0.0193 \\
(0.1008)\end{array}$ & $\begin{array}{l}-0.0210 \\
(0.0354)\end{array}$ & $\begin{array}{l}-0.2875^{* * *} \\
(0.1430)\end{array}$ & $\begin{array}{l}0.0442 \\
(0.0495)\end{array}$ & $\begin{array}{l}0.0032 \\
(0.0421)\end{array}$ & $\begin{array}{l}-0.0351 \\
(0.0482)\end{array}$ & $\begin{array}{l}0.0521 \\
(0.4006)\end{array}$ & $\begin{array}{l}0.0552 \\
(0.0771)\end{array}$ \\
\hline TOBIN'S Q & $\begin{array}{l}-0.0521 * * * \\
(0.0106)\end{array}$ & $\begin{array}{l}-0.0514 * * * \\
(0.0105)\end{array}$ & $\begin{array}{l}-0.0537 * * * \\
(0.0106)\end{array}$ & $\begin{array}{l}-0.0519 * * * \\
(0.0110)\end{array}$ & $\begin{array}{l}-0.0509 * * * \\
(0.0102)\end{array}$ & $\begin{array}{l}-0.0510^{* * * *} \\
(0.0104)\end{array}$ & $\begin{array}{l}-0.0509 * * * \\
(0.0105)\end{array}$ & $\begin{array}{l}-0.0561 \text { *** } \\
(0.0112)\end{array}$ \\
\hline TOTAL ASSETS & $\begin{array}{l}0.0069 \\
(0.0044)\end{array}$ & $\begin{array}{l}0.0070 \\
(0.0045)\end{array}$ & $\begin{array}{l}0.0061 \\
(0.0045)\end{array}$ & $\begin{array}{l}0.0074 * * \\
(0.0044)\end{array}$ & $\begin{array}{l}0.0074 * \\
(0.0045)\end{array}$ & $\begin{array}{l}0.0057 \\
(0.0044)\end{array}$ & $\begin{array}{l}0.0066 \\
(0.0043)\end{array}$ & $\begin{array}{l}0.0069 \\
(0.0044)\end{array}$ \\
\hline INSTITUTIONAL & $\begin{array}{l}0.0015 \\
(0.0024)\end{array}$ & $\begin{array}{l}0.0010 \\
(0.0024)\end{array}$ & $\begin{array}{l}0.0013 \\
(0.0024)\end{array}$ & $\begin{array}{l}0.0013 \\
(0.0024)\end{array}$ & $\begin{array}{l}0.0014 \\
(0.0024)\end{array}$ & $\begin{array}{l}0.0014 \\
(0.0025)\end{array}$ & $\begin{array}{l}0.0013 \\
(0.0024)\end{array}$ & $\begin{array}{l}0.0013 \\
(0.0024)\end{array}$ \\
\hline VOLATILITY & $\begin{array}{l}0.3302 * * * \\
(0.1059)\end{array}$ & $\begin{array}{l}0.2880 * * * \\
(0.1073)\end{array}$ & $\begin{array}{l}0.3225 * * * \\
(0.1029)\end{array}$ & $\begin{array}{l}0.3079 * * * \\
(0.0981)\end{array}$ & $\begin{array}{l}0.2758 * * \\
(0.1078)\end{array}$ & $\begin{array}{l}0.3063^{* * * *} \\
(0.0993)\end{array}$ & $\begin{array}{l}0.3187 * * * \\
(0.1009)\end{array}$ & $\begin{array}{l}0.3112 * * * \\
(0.1020)\end{array}$ \\
\hline RETURN & $\begin{array}{l}-0.7893 * * * \\
(0.1791)\end{array}$ & $\begin{array}{l}-0.7289 * * * \\
(0.1738)\end{array}$ & $\begin{array}{l}-0.7916 * * * \\
(0.1775)\end{array}$ & $\begin{array}{l}-0.7705 * * * \\
(0.1807)\end{array}$ & $\begin{array}{l}-0.7390 \text { **** } \\
(0.1691)\end{array}$ & $\begin{array}{l}-0.7293 * * * \\
(0.1849)\end{array}$ & $\begin{array}{l}-0.7581 * * * \\
(0.1743)\end{array}$ & $\begin{array}{l}-0.7899 \text { *** } \\
(0.1784)\end{array}$ \\
\hline LEVERAGE & $\begin{array}{l}0.0002 \\
(0.0216)\end{array}$ & $\begin{array}{l}0.0003 \\
(0.0224)\end{array}$ & $\begin{array}{l}0.0002 \\
(0.0235)\end{array}$ & $\begin{array}{l}0.0002 \\
(0.0245)\end{array}$ & $\begin{array}{l}0.0002 \\
(0.0233)\end{array}$ & $\begin{array}{l}0.0001 \\
(0.0236)\end{array}$ & $\begin{array}{l}0.0001 \\
(0.0234)\end{array}$ & $\begin{array}{l}0.0002 \\
(0.0261)\end{array}$ \\
\hline CASHFLOW & $\begin{array}{l}0.0396 \\
(0.0628)\end{array}$ & $\begin{array}{l}0.0507 \\
(0.0650)\end{array}$ & $\begin{array}{l}0.0627 \\
(0.0639)\end{array}$ & $\begin{array}{l}0.0544 \\
(0.0636)\end{array}$ & $\begin{array}{l}0.0558 \\
(0.0610)\end{array}$ & $\begin{array}{l}0.0544 \\
(0.0629)\end{array}$ & $\begin{array}{l}0.0373 \\
(0.0619)\end{array}$ & $\begin{array}{l}0.0712 \\
(0.0636)\end{array}$ \\
\hline$\chi^{2}$ & $71.18 * * *$ & $87.42 * * *$ & $72.01 * * *$ & $76.82 * * *$ & $78.92 * * *$ & $88.59 * * *$ & $84.40 * * *$ & $68.83 * * *$ \\
\hline
\end{tabular}




\section{Table 8}

Combination of restructuring strategies: The dependent variable (Recovery) takes the value of 1 when a financial distress firm increases its distance-to-default in two consecutive years followed the distress year, and zero otherwise. Birth takes the value of 1 if a firm is in this stage and zero otherwise. Growth takes the value of 1 if a firm is in this stage and zero otherwise. Mature takes the value of 1 if a firm is in this stage and zero otherwise. There are eight recovery strategies that may be undertaken by distress firms under the managerial, operational, assets and financial restructuring. NumStrategies takes the value of 1 when at least 2, 3, or 4 recovery strategies are undertaken concurrently, and zero otherwise. Definitions of restructuring are in Table 2. TobinsQ is measured by (Market capitalization) + Total Asset - Common/Ordinary Equity, scaled by total assets. LnTotalAssets is measured by $\operatorname{Ln}$ (Total Assets). Institutional is measured by the total share holdings held by institutional investors, scaled by the total outstanding shares. Volatility is the standard deviation of the monthly stock returns. Return is the mean of the monthly stock returns. Leverage is the ratio of the book value of long term debt divided by the value of the firm. CashFlow is the ratio of net cash flow from operations divided by total assets. The bootstrapped standard errors are in brackets. ***, **, and $*$ denote statistical significance at the $1 \%, 5 \%$ and $10 \%$ levels respectively.

\begin{tabular}{|c|c|c|c|c|}
\hline & $\begin{array}{l}1) \\
\text { At least } 2 \\
\text { strategies }\end{array}$ & $\begin{array}{l}(2) \\
\text { At least } 3 \\
\text { strategies }\end{array}$ & $\begin{array}{l}(3) \\
\text { At least } 4 \\
\text { strategies }\end{array}$ & $\begin{array}{l}\text { (4) } \\
\text { At least } 5 \\
\text { strategies }\end{array}$ \\
\hline $\mathrm{C}$ & $\begin{array}{l}0.3119 * * * \\
(0.0389)\end{array}$ & $\begin{array}{l}0.3244 * * * \\
(0.0383)\end{array}$ & $\begin{array}{l}0.3327 * * * \\
(0.0386)\end{array}$ & $\begin{array}{l}0.3346 * * * \\
(0.0393)\end{array}$ \\
\hline BIRTH & $\begin{array}{l}0.0033 \\
(0.0641)\end{array}$ & $\begin{array}{l}-0.0728 \\
(0.0491)\end{array}$ & $\begin{array}{l}-0.0600 \\
(0.0438)\end{array}$ & $\begin{array}{l}-0.0429 \\
(0.0424)\end{array}$ \\
\hline GROWTH & $\begin{array}{l}-0.0016 \\
(0.0325)\end{array}$ & $\begin{array}{l}0.0133 \\
(0.0259)\end{array}$ & $\begin{array}{l}0.0109 \\
(0.0239)\end{array}$ & $\begin{array}{l}0.0092 \\
(0.0240)\end{array}$ \\
\hline MATURE & $\begin{array}{l}-0.0189 \\
(0.0245)\end{array}$ & $\begin{array}{l}-0.0054 \\
(0.0205)\end{array}$ & $\begin{array}{l}-0.0120 \\
(0.0190)\end{array}$ & $\begin{array}{l}-0.0097 \\
(0.0187)\end{array}$ \\
\hline NUMSTRATEGIES & $\begin{array}{l}0.0486 * * \\
(0.0200)\end{array}$ & $\begin{array}{l}0.0554 * \\
(0.0290)\end{array}$ & $\begin{array}{l}0.0297 \\
(0.0505)\end{array}$ & $\begin{array}{l}0.1717 \\
(0.1466)\end{array}$ \\
\hline BIRTH* NUMSTRATEGIES & $\begin{array}{l}-0.0959 \\
(0.0763)\end{array}$ & $\begin{array}{l}-0.0631 \\
(0.0877)\end{array}$ & $\begin{array}{l}0.0971 \\
(0.1443)\end{array}$ & $\begin{array}{l}-0.3659 * \\
(0.2065)\end{array}$ \\
\hline GROWTH* NUMSTRATEGIES & $\begin{array}{l}0.0145 \\
(0.0436)\end{array}$ & $\begin{array}{l}-0.0231 \\
(0.0533)\end{array}$ & $\begin{array}{l}-0.0076 \\
(0.0829)\end{array}$ & $\begin{array}{l}-0.0017 \\
(0.2204)\end{array}$ \\
\hline MATURE* NUMSTRATEGIES & $\begin{array}{l}0.0168 \\
(0.0339)\end{array}$ & $\begin{array}{l}-0.0334 \\
(0.0460)\end{array}$ & $\begin{array}{l}0.0410 \\
(0.0814)\end{array}$ & $\begin{array}{l}-0.1302 \\
(0.1932)\end{array}$ \\
\hline TOBIN'S Q & $\begin{array}{l}-0.0520 * * * \\
(0.0104)\end{array}$ & $\begin{array}{l}-0.0523 * * * \\
(0.0101)\end{array}$ & $\begin{array}{l}-0.0536 \text { **** } \\
(0.0106)\end{array}$ & $\begin{array}{l}-0.0542 * * * \\
(0.0098)\end{array}$ \\
\hline TOTAL ASSETS & $\begin{array}{l}0.0072 \\
(0.0045)\end{array}$ & $\begin{array}{l}0.0069 \\
(0.0044)\end{array}$ & $\begin{array}{l}0.0066 \\
(0.0045)\end{array}$ & $\begin{array}{l}0.0065 \\
(0.0047)\end{array}$ \\
\hline INSTITUTIONAL & $\begin{array}{l}0.0013 \\
(0.0023)\end{array}$ & $\begin{array}{l}0.0013 \\
(0.0024)\end{array}$ & $\begin{array}{l}0.0013 \\
(0.0024)\end{array}$ & $\begin{array}{l}0.0012 \\
(0.0024)\end{array}$ \\
\hline VOLATILITY & $\begin{array}{l}0.2719 * * * \\
(0.1055)\end{array}$ & $\begin{array}{l}0.2909 * * * \\
(0.1030)\end{array}$ & $\begin{array}{l}0.3155^{* * *} \\
(0.1016)\end{array}$ & $\begin{array}{l}0.3255^{* * * *} \\
(0.1028)\end{array}$ \\
\hline RETURN & $\begin{array}{l}-0.7370 * * * \\
(0.1766)\end{array}$ & $\begin{array}{l}-0.7364 * * * \\
(0.1730)\end{array}$ & $\begin{array}{l}-0.7693 \text { *** } \\
(0.1825)\end{array}$ & $\begin{array}{l}-0.7739 * * * \\
(0.1735)\end{array}$ \\
\hline LEVERAGE & $\begin{array}{l}0.0002 \\
(0.0231)\end{array}$ & $\begin{array}{l}0.0001 \\
(0.0214)\end{array}$ & $\begin{array}{l}0.0002 \\
(0.0249)\end{array}$ & $\begin{array}{l}0.0002 \\
(0.0245)\end{array}$ \\
\hline CASHFLOW & $\begin{array}{l}0.0639 \\
(0.0638)\end{array}$ & $\begin{array}{l}0.0608 \\
(0.0619)\end{array}$ & $\begin{array}{l}0.0617 \\
(0.0644)\end{array}$ & $\begin{array}{l}0.0521 \\
(0.0611)\end{array}$ \\
\hline$\chi^{2}$ & $83.47 * * *$ & $73.30 * * *$ & $70.70 * * *$ & $81.66 * * *$ \\
\hline
\end{tabular}


Table 9

Odds ratios for restructuring strategies: This table presents the odds ratios associated with the estimates of presented in Table 7 (Panel A) and Table 8 (Panel B).***,**, and * denote statistical significance at the $1 \%, 5 \%$ and $10 \%$ levels respectively.

\begin{tabular}{|c|c|c|c|c|c|c|c|c|}
\hline \multicolumn{9}{|l|}{ Panel A } \\
\hline & (1) & $(2)$ & (3) & (4) & $(5)$ & (6) & (7) & $(8)$ \\
\hline & CEO & INV & COGS & EMP & ASSETS & DIV & NetDebt & NetEquity \\
\hline Restructuring & 0.8200 & $\begin{array}{l}1.2739 * * \\
*\end{array}$ & 1.6794 & 1.0932 & 1.0616 & $1.3002 * * *$ & $0.8926^{*}$ & 1.0382 \\
\hline Birth * Restructuring & $7.5660 *$ & 0.4884 & Omitted & 0.7186 & 1.9586 & $0.1461 * * *$ & 1.7543 & 1.3754 \\
\hline Growth $*$ Restructuring & 0.6651 & 1.3636 & 0.3610 & 1.0941 & 1.3345 & 0.8165 & 0.8165 & 1.4840 \\
\hline Mature * Restructuring & 0.9178 & 0.9081 & $0.2557 * *$ & 1.1715 & 1.0082 & 0.8999 & 1.2370 & 1.3366 \\
\hline \multicolumn{9}{|l|}{ Panel B } \\
\hline & \multicolumn{2}{|c|}{$(1)$} & \multicolumn{2}{|c|}{ (2) } & \multicolumn{2}{|c|}{ (3) } & \multicolumn{2}{|r|}{ (4) } \\
\hline & \multicolumn{2}{|c|}{ At least 2} & \multicolumn{2}{|c|}{ At least 3} & \multicolumn{2}{|c|}{ At least 4} & \multicolumn{2}{|r|}{ At least 5} \\
\hline & \multicolumn{2}{|c|}{ Strategies } & \multicolumn{2}{|c|}{ Strategies } & \multicolumn{2}{|c|}{ Strategies } & \multicolumn{2}{|r|}{ Strategies } \\
\hline NumStrategies & \multicolumn{2}{|c|}{$1.2109 * *$} & \multicolumn{2}{|c|}{$1.2434 *$} & \multicolumn{2}{|c|}{1.0744} & \multicolumn{2}{|r|}{1.7730} \\
\hline Birth * NumStrategies & \multicolumn{2}{|c|}{0.6510} & \multicolumn{2}{|c|}{1.6666} & \multicolumn{2}{|c|}{2.0396} & \multicolumn{2}{|r|}{$1.000 *$} \\
\hline Growth * NumStrategies & \multicolumn{2}{|c|}{1.1017} & \multicolumn{2}{|c|}{0.9292} & \multicolumn{2}{|c|}{1.0173} & \multicolumn{2}{|r|}{1.5140} \\
\hline Mature * NumStrategies & \multicolumn{2}{|c|}{1.0741} & \multicolumn{2}{|c|}{0.8519} & \multicolumn{2}{|c|}{1.2836} & \multicolumn{2}{|r|}{0.6380} \\
\hline
\end{tabular}




\section{Figure 1}

Distress firms (by lifecycle) from 1995 to 2013

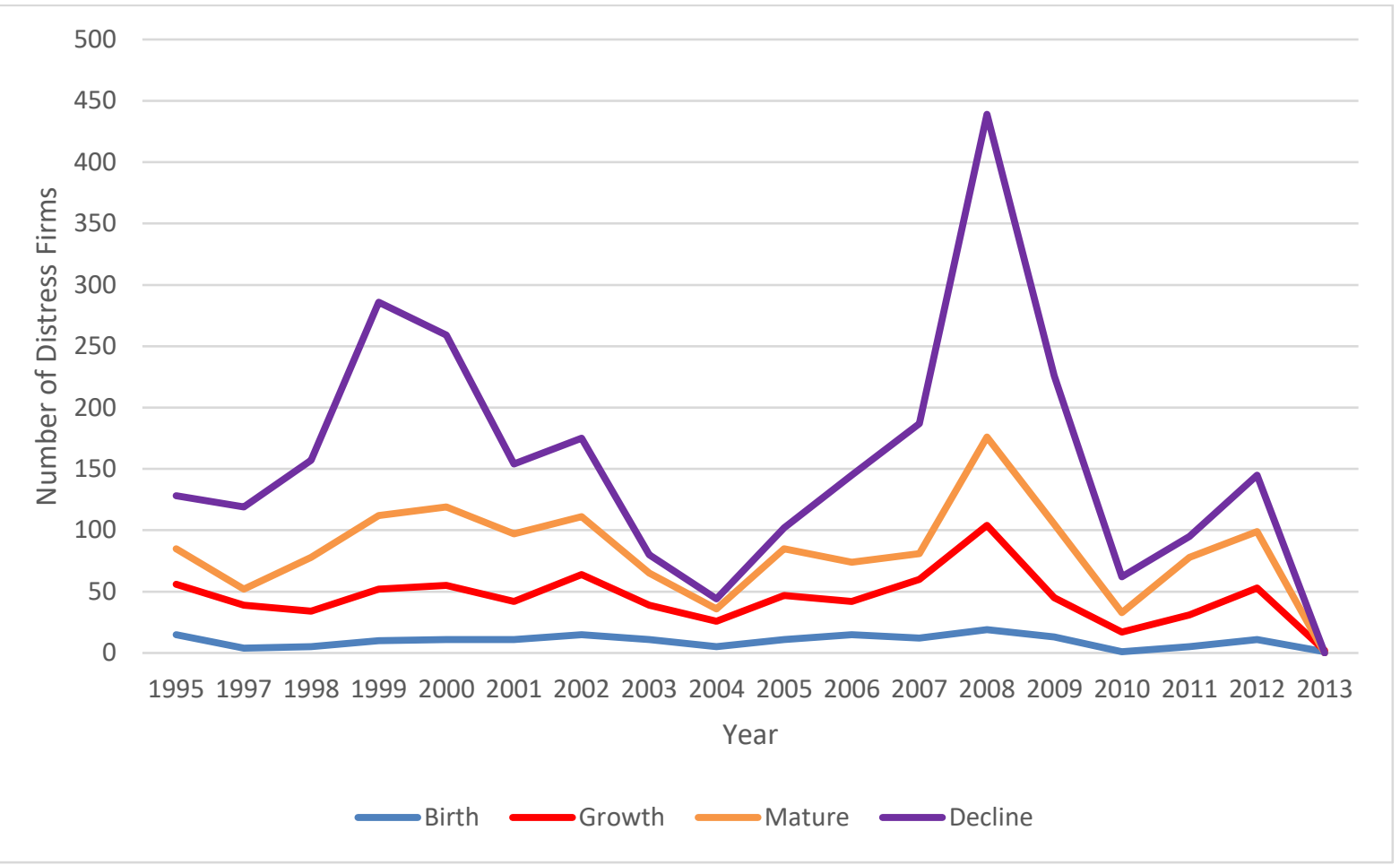

